ORIGINAL ARTICLE

Received:202/06/29

Accepted:2021/04/19

\title{
Effectiveness of Acceptance and Commitment Therapy on Resilience, Psychological Well- Being, and Life Expectancy in Asthmatic Patients
}

\author{
Shaghayegh Bahramiabdolmalaki (M.A.) $)^{1}$, Alireza Homayouni (Ph.D.) $)^{2}$, Masoud Aliyali (Ph.D.) ${ }^{3}$
}

1.M.A, Department of Psychology, Bandargaz Branch, Islamic Azad University, Bandargaz Branch Bandargaz, Iran. 2.Correspounding Author: Assistance Professor, Department of Psychology, Bandargaz Branch, Islamic Azad University, Bandargaz, Iran. Email: homaiony@gmail.com Tel: 09112181040

3.Associate Professor, Department of internal medicine, pulmonary and critical care division, Mazandaran University of medical sciences, Sari, Iran.

\begin{abstract}
Introduction: Psychosomatic experts have tried to associate mental disorders to physical illnesses. The vulnerability of different parts of the body is thought to depend on fundamental differences between individuals. One of the methods that seems to affect the psychological problems of asthma patients is acceptance and commitment therapy. Therefore, the aim of this study was to evaluate the effectiveness of acceptance- and commitment-based therapy on resilience, psychological well-being, and life expectancy in asthmatic patients.

Methods: This quasi-experimental pre-test and post-test study was conducted on 30 asthmatic patients who were randomly assigned to the experimental $(n=15)$ and control $(n=15)$ groups according to the inclusion criteria. Acceptance and commitment therapy sessions were based on the treatment package of Hayes et al. in 8 sessions of 60 minutes on the experimental group and no intervention was performed on the control group. All participants took part in the pre-test and post-test. Collection tools included Conner-Davidson Resilience Questionnaire, Schneider Life expectancy, and Ryf Psychological Well-being.

Results: The results showed a significant difference in the components of resilience, psychological wellbeing, and life expectancy in asthmatic patients before and after the experiment $(\mathrm{p}<0.05)$. In other words, acceptance and commitment-based therapy had a positive effect on resilience, psychological well-being and life expectancy in asthmatic patients and these components have increased in patients.

Conclusion: Findings showed that acceptance- and commitment-based therapy was effective on resilience, psychological well-being, and life expectancy of asthmatic patients. This treatment is suggested to be used in conjunction with drug therapy to improve the psychological symptoms of asthmatic patients.
\end{abstract}

Keywords: Acceptance and Commitment Therapy, Resiliency, Psychological Well-being, Life Expectancy, asthmatic

Conflict of interest: The authors declared that there is no conflict interest.

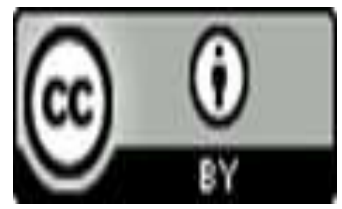

This Paper Should be Cited as:

Author: Shaghayegh Bahramiabdolmalaki, Alireza Homayouni, Masoud Aliyali.

Effectiveness of Acceptance and Commitment Therapy on Tolooebehdasht Journal.2021;20(1):55-68.[Persian] 

اجراى جلسات بيش آزمون و بِ آزمون از هر دو گروه گرفته شد. ابزار گردآورى شامل يرسشنامه هاى تاب آورى كونر ديويدسون، اميد به زندگى اشنايدر و بهزيستى روانشناختى ريف بود. يافته ها: نتايج نشان داد كه تفاوت معنى دارى در مولفه هاى تاب آورى، بهزيستى روانشناختى و اميد به

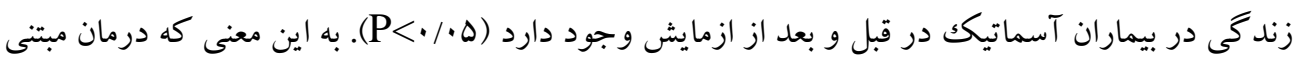
بر يذيرش و تعهد بر تاب آورى، بهزيستى روانشناختى و اميد به زندگى در بيماران آسماتيك اثر مثبت داشته و اين مولفه ها در بيماران افزايش يافته است.

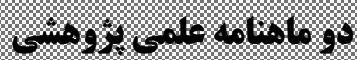

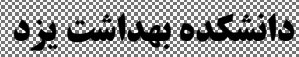
ping

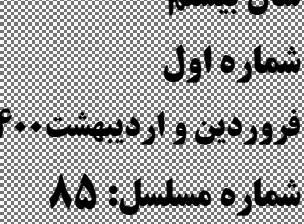

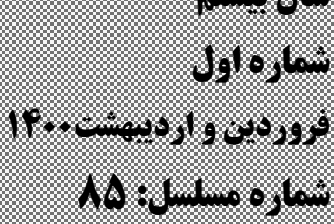

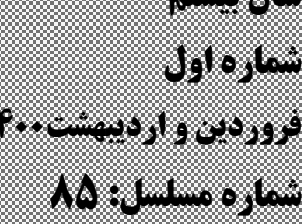

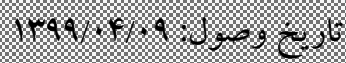

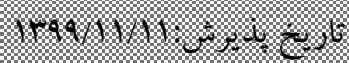
نتيجه كيرى: يافته ها نشان داد درمان مبتنى بر يذيرش و تعهد بر ميزان تاب آورى، بهزيستى روانشناختى

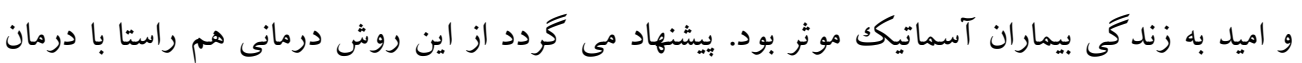
دارويى در بهبود علايم روانشناختى بيماران آسماتيك استفاده شود.

وازههاى كليدى: درمان مبتنى بر يذيرش و تعهد، تاب آورى، بهزيستى روانشناختى، اميد به زندگى، آسماتيك

اثربخشى درمان مبتنى بر يذيرش و تعهد بر تاب آورى، بهزيستى روانشناختى و اميد به زندكى در بيماران آسماتيكى

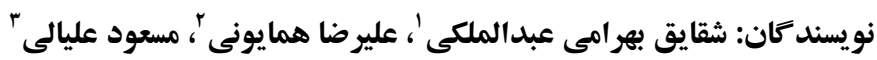

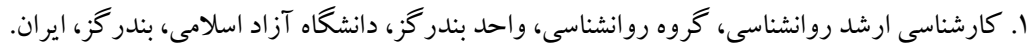

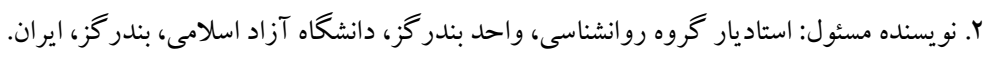

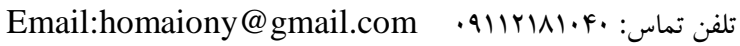
r.دانشيار گروه طب داخلى، بيماريهاى ريه و مر اقبتهاى ويزه، دانشكاه علوم يز شكى مازندران، سارى، ايران.

مقلمه: متخصصان يزشكى روان تنى تلاش كرده اند ارتباط اختلالات روانى و بيمارى هاى جسمى را مشخص كنتد. تصور بر اين است آسيب بذيرى بخشهاى كوناگون بدن به تفاوتهاى اساسى ميان افراد بستكى دارد. يكى از روش هايى كه به نظر مى رسد بر مشكلات روانشناختى بيماران آسم موثر باشد درمان مبتنى بر يذيرش و تعهد است. بنابراين هدف از يثزوهش حاضر بررسى اثربخشى درمان مبتنى بر پذيرش و

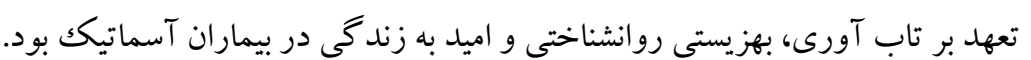
روش بروسى: اين يزوهش نيمه آزمايشى از نوع بيش آزمون و يس آزمون بر روى ·ب بيمار آسمى كه با توجه به معيارهاى ورود به صورت تصادفى به دو گروه آزمايش و كنترل ها نفره منتصب شدند، انجام شد. جلسات درمان يذيرش و تعهد براساس بسته درمانى Hayes و همكاران در ^ جلسه •9 دقيقه اى بر روى گروه آزمايش تشكيل شد و هيج مداخله اى بر روى گروه كنترل صورت نكرفت. قبل و بعد از

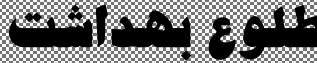

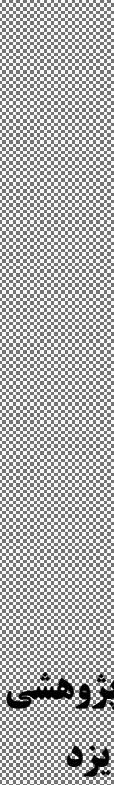


مكاتب مادّى و يوتج گرايى جايكاهى ندارد (F) (IF). توجه به قوانين هستى، ارتباط با خدا و خود، توجه به آفرينش انسان عواملى هستند كه موجب تقويت اميد به زندگى انسان خواهند

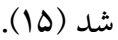
اميد حالت انكيزشى مثبى است كه مبتى بر حس راهيابى است و محصول تعامل فرد با محيط است (19)، و باعث مى شود فرد با وجود موانعى كه در مسير زندگى خود دارد انكيزه خود را

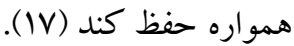
درمان هاى آسم اكثرا به صورت دارويى مى باشند اما در موج سوم اصلاح و تلفيق با رويكرد شناختى رفتارى با اصول اساسى مسوليتها و دركك واقعيت استوارتر شده است و درمان مبتنى بر هُيرش و تعهد ( acceptance and commitment (therapy شناختى به وجود آمدند و بر نقش باورها، طرح وارهها و نظام بردازش اطلاعات در ايجاد اختلالات روانى تاكيد دارد (19). هدف اصلى درمان يذيرش و تعهد ايجاد انعطاف يذيرى روانى

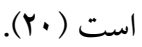

در رويكرد يذيرش و تعهد بر خلاف درمانشناختى رفتارى، محتواى افكار، احساسات و حسهاى بدنى بررسى نمىشوند (Y) (Y)، بلكه شيوههايى كه افراد بدان وسيله به تجارب خويش

$$
\text { مى يردازند، مورد بررسى قرار مى گيرد (Yr). }
$$

در همين راستا يزوهش محمود فخه، خادمى و تسبيح سازان (1) (1) دريافتند كه درمان مبتنى بر بذيرش و تعهد بر بهزيستى روانشناختى مؤثر است (rY).فراهانى و حيدرى (IrqV) نشان
آسم يكك بيمارى تنفسى است كه با حملات اسياسم در برونش ها باعث تنفس سخت مى گردد (1). اين بيمارى معمولا با باسخ هاى آلرزيكك و افزايش حساسيت در ارتباط است. اين بيمارى مى تواند به صورت شديد خود را نشان دهد و در بيمارانى كه علائم شديد دارند اختلالات خلقى شايع است (Y). در بيشتر يُزوهش هاى اوليه، آسم به عنوان بيماريى با علل روانى معرفى شده است (r) و بيماران از تاب آورى يا انعطاف روانشناختى كمترى برخوردار مى باشند (F). تابآورى به (resilience) توانيى ساز كارى موفقيت آميز با شرايط تهديدكنده اطلاق مى شود (ه). تاب آورى را ساز كارى مثبت فرد در واكنش به شرايط ناگوار مىدانند (4). تاب آورى، تنها بايدارى در برابر آسيبها يا شرايط تهديدكننده نيست، بلكه شركت فعال و سازنده فرد در محيط نيز مى باشد (V). تابآورى نوعى ترميم خود با بي آمدهاى مثبت هيجانى، عاطفى و شناختى است (^). از طرف ديغر افراد تاب آور در زمينه بهزيستى روانشناختى (psychological well-being)

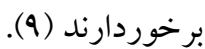

بهزيستى روانشناختى تلاش فرد براى تحقق توانيىهاى بالقوهى واقعى خود است (•l). بهزيستى روانشناختى يك مفهوم جندبعدى شامل وِذيرش خود، روابط مثبت با ديخران، خودمختارى، تسلط بر محيط، زندگى هدفمند و رشد فردى است (11).از جانبى ديخر يكى از مهمترين نيازهاى روانى انسان اميد به زندگى (life expectancy) است (Y ). اميد به زندگى به انسان انخيزه شادابى و نشاط مى دهد (r) (I). 
در درمانكاه ريه كلينيك ويزه شهر سارى تشكيل دادند. تعداد ·r نفر به صورت در دسترس با توجه به معيارهاى ورود به بُزوهش انتخاب شده و به صورت تصادفى به دو گروه آزمايش ها نفره و كنترل ها نفره منتصب شدند. معيارهاى ورود به مطالعه شامل: بيماران آسماتيك با نمره سٓ به بالا در برسشنامه سلامت (GHQ-28)، بازه سنى ·r تا .9 سال كه حداقل r سال از تشخيص آن ها گذشته باشد، شدت بيمارى آسم در سطح متوسط به تشخيص يزشك معالج مركز درمانى، عدم همراهى اختلالات روانى و جسمانى كه در شركت در جلسات درمانى مداخله ايجاد نمايد، عدم دريافت داروهاى تاثير كذار در فرايند همكارى در جلسات، موافقت افراد در خصوص شر كت در طرح بثزهش. معيارهاى خروج از يثزوهش شامل: تكميل ناقص يرسشنامه ها، عدم شركت كردن Y جلسه متوالى، تمايل به خروج از مطالعه در

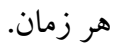
در فرآيند اجرايى در ابتدا در گروه آزمايشى قبل از شروع مداخله توضيحاتى در خصوص هدف مطالعه و حفظ رازدارى مطالب به آزمودنى ها داده شد و جلسات درمان بذيرش و تعهد در كلينيك درمانى تشكيل شد و محتواى جلسات يُوهش 4. براساس بسته درمانى Hayes و همكاران (•r) در ^ جلسه دقيقه اى بر روى گروه آزمايش انجام شد( جدول (). هيج مداخله اي طى اين مدت بر روى گروه كنترل صورت نخرفت. قبل از اجر ایى جلسات، ييش آزمون از هر دو گروه تهيه شد و در پايان جلسات از هر دو گروه بِ آزمون گرفته شد.
دادند كه درمان مبتى بر يذيرش و تعهد باعث افزايش تاب

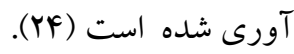
Passmore تعهد بر ارتقا سلامت و بهزيستى روانشناختى اثر دارد (YD). Hughes با بهبود وضعيت روانشناختى و افزايش تاب آورى و انعطاف روانشناختى اثر دارد. از طرفى يززوهش ها نشان مىدهد كه بين ب ك تا F درصد كل جمعيّت به آسم دهارند (YV). افراد مبتلا به آسم زير فشارهاى روانى زيادى قرار دارند (YN). نتايج اخير نشان دهنده وجود رابطه ميان نوع سيستم مغزى رفتارى با آسيب روانى و مشكلات همراه شامل نقش بردازش شناختى و بيمارى جسمى مانند آسم مى باشد (Y9). اين بيمارى با توجه به شدت آن مى تواند حتى جان افراد را به خظر بيندازد، بنابراين لزوم استفاده از درمان هاى متفاوت از جمله درمان هاى روانشناختى كه در اين بيمارى بسيار نقش دارد

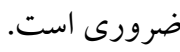
به طور كلى هدف اصلى اين يُوهش ارزيابى اثر درمان مبتى بر يذيرش و تعهد بر تاب آورى، بهزيستى روانشناختى و اميد به زندگى در بيماران آسماتيك با سلامت روان بايين مى باشد.

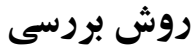
روش تحقيق حاضر از نوع شبه آزمايشى از نوع ييش آزمون و يس آزمون براى دو گروه آزمايش و كنترل بود. جامعه آمارى يُزوهش حاضر را افراد مبتلا به بيمارى آسم با سلامت روانى يايين (مطابق با نقطه برش يرسشنامه سلامت روان GHQ-28) 
جدول ا: خلاصه جلسات درمانى مبتنى بر يذيرش و تعهد

جلسه هلف هو خلاصه هر جلسه

جلسه اول: مقدمه، به مراجعان تعداد جلسات و ساعات شركت در جلسات درمانى، اهداف و سير درمان توضيح داده شده است. بحث در مورد حدود رازدارى، تصريح نوع رابطه درمان: با استفاده از استعاره دو كوه. سنجش كلى: از مراجعان خواسته شد افكار و اعمال خود را توصيف كنند، مقدمهاى به درماندگى خلاق. ارائه تكليف جلسه دوم: سنجش عملكرد : در ابتداى هر جلسه بررسى گرديد تا مشخص شود كه امور خارج از جلسه براى شركت كنند كان در درمان جُخونه بوده است. مرور واكنشها به جلسه قبل، مرور تكليف: اكر مراجع تكليف را انجام نمىداد، درمانكر متغيرهاى عامل را بررسى مى كرد. ادامه درماندكى خلاق، ارائه تكليف جلسه سوم: سنجش عملكرد، مرور واكنش به جلسه قبل، مرور تكليف، در اين مرحله با توجه به اين كه درماندگى خلاق، كنترل به عنوان

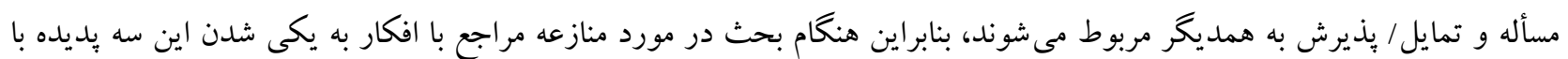

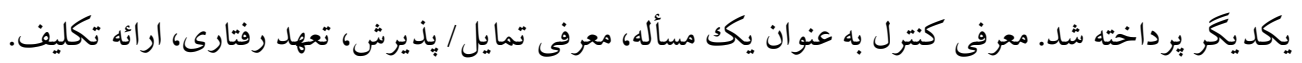
جلسه جهارم : سنجش عملكرد، مرور واكنشها به جلسه قبل، مرور تكليف و تعهد رفتارى، معرفى خود به عنوان زمينه و كسلش. جلسه ينج : تمرين تعهد رفتارى: درمانخر به هر يكك از شركت كنند كان فرصت داد تا به تمرينات تمايل ادامه دهند. اين تمرينات تمايل كه لازم است در طول دوره درمان ادامه داشته باشد باعث ميشوند تا مراجع تعهداتش رادر جريان درمان افزايش بدهد. جلسه ششم: سنجش عملكرد، مرور واكنشها به جلسه قبل، مرور تكليف، معرفى ارزشها (دادن تكليف ارزش ها)، اين عمل با تكميل برسشنامه سنجش ارزش ها انجام گرفت تا با تصريح ارزشهاى مراجع به هدايت مراجع خارج از حمايت درمانگر كمكك شود. جلسه هفتم: سنجش عملكرد، مرور واكنشها به جلسه قبل، مرور تكليف و تعهد رفتارى، معرفى خود به عنوان زمينه و كسلش. جلسه هشتم: سنجش عملكرد، مرور واكنشها به جلسه قبل، مرور تكليف و تعهد رفتارى، معرفى خود به عنوان زمينه و گسلش، معرفى ارزش ها، جمع بندى جلسات

• تا ..1 است. هر جهه اين امتياز بالاتر باشد، بيانگر تاب آورى بيشتر فرد يِاسخ دهنده مى باشد و برعكس. روايى همكراى اين ״رسشنامه با استفاده از يرسشنامه سرسختى كوباسا روى ·r نفر انجام شده و نتايج نشان داد كه :يرسشنامه تابآورى با ״يرسشنامهى سرسختى كوباسا r//• ارتباط دارد، ولى با استرس ادراكك شده V9/.-- رابطه دارد و نشان مىدهد كه سطح بالاى تابَآورى با استرس تجربه شده يايين ارتباط دارد و هم جنين يايايى آزمون - باز آزمون اين برسشنامه AV/ • محاسبه شد (V). به طور كلى نتايج نشان از يايايى و روايى مطلوب برسشنامه تابآورى را نشان مىدهد. در ايران جو كار (اسM) روايى سازه و
در اين يثوهش از يرسشنامه هاى تاب آورى، اميد به زندگى، بهزيستى روانشناختى، و سلامت عمومى استفاده شد. اين يرسشنامه توسط Davidson \& Connor در سال r... با ro سوال طراحى شد (V) و در طيف ليكرت از كاملاً

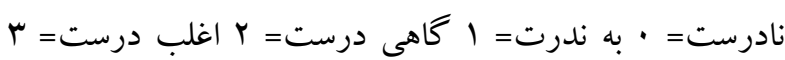
هميشه درست = أنمره كذارى مى شود و داراى يك نمره كل است. در اين پرسشنامه حداكثر نمره ..1 و حداقل نمره صفر مىباشد و نمرهى هر آزمودنى برابر مجموع نمرات از هر يكك از سوالات است. براى بدست آوردن امتياز كلى برسشنامه، مجموع امتيازات همه سوالات با هم جمع مى شود. اين امتياز دامنه ایى از 
بذيرش خود، روابط مثبت با ديخران، خودمختارى، تسلط بر محيط، زندگى هدفمند و رشد فردى است، و يكك نمره كل

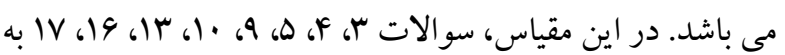
صورت معكوس نمره كذارى مى شود و بقيه سوالات به صورت مستقيم نمره گذارى مى شوند. نمره بالاتر در اين برسشنامه نشان دهنده بهزيستى روانشناختى بيشتر فرد مى باشد. ريف روايى سازه و همزمان ابزار را تاييد و يايايى آن را در يُزوهشهاى مختلف با روش آلفاى كرونباخ براى خرده مقياس استقلال

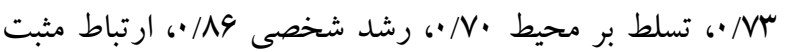

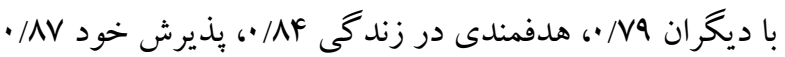
و كل آن A9/، گزارش نمود. هم جنين خانجانى و همكاران (11) روايى سازه و همزمان را تاييد و ويايايى آن را با روش آلفاى كرونباخ براى استقلال •/V•، تسلط بر محيط 199•، رشد شخصى /Ar/•، ارتباط مثبت با ديخران NV/، هدفمندى در

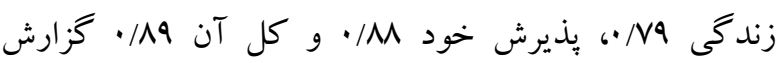
كردند. در يزوهش حاضر پايايى به روش آلفاى كرونباخ براى استقلال 199•، تسلط بر محيط 90/،، رشد شخصى مثبت با ديخر ان NA/•، هدفمندى در زندگى •^//•، بذيرش خود (AF • • و كل آن • • • بدست آمد.

برسشنامة سلامت عمومى توسط Goldberg و همكاران در سال laVY ساخته شد (Dr). به صورت F كزينهاى است و ياسخ آزمودنى به هر سؤال در يكك طيف جهار درجهاى (اصلاً، در حد معمول، به مراتب بيشتر از حد معمول، تقريباً بيشتر از حد معمول) مشخص مى شوند. نمره بالاتر نشان دهنده وضعيت بدتر است و نقطه برش آن بr است، اين برسشنامه از ع زير مقياس علائم جسمانى، اضطراب، اختلال در كاركرد اجتماعى،
محتوا را تاييد نمود و بايايى به روش ضريب آلفاى كرونباخ را

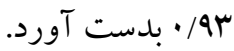
يرسشنامه اميد به زندگى توسط Snyder و همكاران در سال 1991 با با سوال طراحى شده است (Yr) و در Y بعد (اتفكر

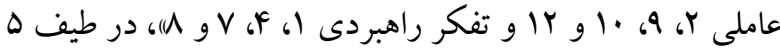
كزينهاى ليكرت (خيلى كم، كم، متوسط، زياد و خيلى زياد) طراحى شده است كه به ترتيب از ا تا ه نمره گذارى مىشوند. همجنين در اين بِرسشنامه سوالهاى ا، ه، V و لا به عنوان سوالهاى انحرافى درنظر گرفته شد. براى بدست آوردن امتياز كلى برسشنامه، مجموع امتيازات تكك تكك سوالات با هم محاسبه مى شوند. امتيازات بالاتر، نشان دهنده اميد به زندگى بيشتر در فرد باسخ دهنده خواهد بود و برعكس. شواهد اوليه در مورد اعتبار و بايايى اين آزمون توسط اشنايدر و همكاران فراهم شده است. تحليل عامل اكتشافى دو مولفه تفكر عاملى و تفكر راهبردى مقياس را تأييد كرده اند. آلفاى كرونباخ برسشنامه بين

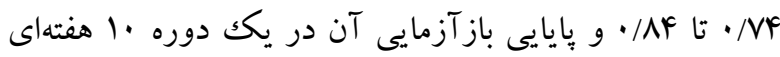
•^/· بهدست آمده است. روايى محتوا و سازه اين مقياس در ايران در يثوهش علاءالدينى، كجباف و مولوى (سب) تأييد شده است و پايايى به روش الفاى كرونباخ براى دو عامل تفكر عاملى

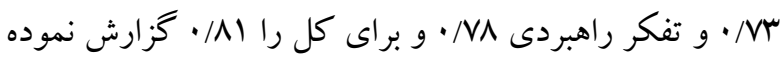

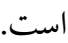
اين يُرسنامه توسط Ryff و همكاران در سال r...r سوال ساخته شد (YF). اين مقياس \ا گويه دارد و نمره گذارى آن براساس طيف ليكرت شش درجهاى از 1 (كاملاً مخالفم) تا 9 (كاملاً مو افقم) مى باشد؛ حداقل نمره قابل كسب در اين مقياس 1ا و حداكثر نمره 1·1 مى باشد و و داراى شش خرده مقياس 
نرمالى داده ها تاييد گرديد و سجّس از روش تحليل كوواريانس جند متغيره براى تجزيه تحليل داده ها استفاده شد.

اطلاعات جمعيت شناختى گروه نمونه در شاخص هاى متفاوت جمعيت شناختى در دو گروه آزمايش و كنترل نشان داده مى شود.

در وضعيت شغلى در گروه ازمايش rا نفر شغل ازاد و r نفر خانه دار، و در گروه كنترل لنفر شغل ازادو ^ نفر خانه دار

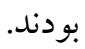
در وضعيت تحصيلى در گروه آزمايش \& نفر زير دييلم، ه نفر دييلم، و ץ نفر ليسانس و بالاتر، و در گروه كنترل ه نفر زير دييلم، ونفر دييلم، و F نفر ليسانس و بالاتر بودند (جدول Y). شاخص هاى توصيفى همجِون ميانگين و انحر اف استاندارد متغير تاب آورى و خرده مقياس هاى اميد به زندگى و بهزيستى روانشناختى در گروه آزمايش و كنترل در بيش آزمون و پِ آزمون را نشان مى دهد. در بررسى ييش فرض ها آزمون همگنى باكس، آزمون لوين و شيب رگرسيون تاييد شد، بنابراين بيش فرض استفاده از آزمون تحليل كوواريانس جند متغيره

$$
\text { رعايت شده است (جدول r). }
$$

افسردگى و يكك نمره كلى سلامت تشكيل شده است. روايى سازه و محتوا توسط سازند كان تاييد شد و بايايى به روش آلفاى كرونباخ برابر با به/· بدست آمد در ايران نوربالا و همكاران (צr) روايى سازه و محتوا را تاييد و بِايايى به روش آلفاى كرونباخ را •9/• بدست آوردند و در يزوهش حاضر هيايايى كل

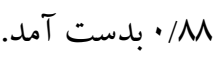
در اين يُوهش براى تاييد توزيع نرمال داده ها از آزمون هاى كشيدگى و جولخى، و شاييرو ويلكز استفاده شد. بيش فرض ها با استفاده از آزمون همخنى باكس، آزمون لوين و شيب ركرسيون نيز بررسى شدند. براى تجزيه و تحليل اطلاعات بدست آمده از روش تحليل كوواريانس جند متغيره با نرم افزار SPSS

اين مطالعه در كميته اخلاق دانشكاه آزاد اسلامى بندرگز با شناسه اخلاق IR.MAZUMS.RCE.1398.1243 در رشته روانشناسى عمومى مورد تاييد قرار گرفته است.

\section{يافتهها}

در ابتدا بيش فرض هاى آمارى با استفاده از آزمون هاى كشيدگى و جولكى، جعبه ای، شاييرو ويلكز بررسى شد و

جدول ז: مشخصات جمعيت شناختى نمونه هاى دو گروه

\begin{tabular}{|c|c|c|c|c|c|}
\hline \multicolumn{2}{|c|}{ كنترل } & \multicolumn{2}{|c|}{ آزمايش } & \multirow{2}{*}{ عوامل جمعيتى } & \multirow{2}{*}{ متغير ها } \\
\hline درصد & تعداد & درصد & تعداد & & \\
\hline $49 / V$ & v & $\wedge$. & ir & آزاد & \\
\hline$\Delta r / r$ & $\wedge$ & r. & $r$ & خانه دار & وصعيـ سعلى \\
\hline$r / r$ & $\Delta$ & $r 9 / V$ & F & زير دييلم & \\
\hline f. & 9 & 4. & 9 & دييلم & وضعيت تحصيلى \\
\hline$r g / V$ & r & Ir/r & r & ليسانس و بالاتر & \\
\hline
\end{tabular}




\begin{tabular}{|c|c|c|c|c|c|c|c|c|}
\hline \multicolumn{4}{|c|}{ كنترل } & \multicolumn{4}{|c|}{ آزمايش } & \multirow{3}{*}{ متغير } \\
\hline \multicolumn{2}{|c|}{ ״س آزمون } & \multicolumn{2}{|c|}{ يِيش آزمون } & \multicolumn{2}{|c|}{ يِش آزمون } & \multicolumn{2}{|c|}{ بيش آزمون } & \\
\hline انحر اف معيار & ميانگين & انحر اف معيار & ميانغين & انحراف معيار & ميانغين & انحر اف معيار & ميانغين & \\
\hline$r / 99 Y$ & $\mid F / 9 V$ & T/YFV & $1 F / 9$. & F/IrA & IN/AV & $r / F \Delta \Delta$ & $\mid F / A$ & تاب آورى \\
\hline$r / 9 \cdot 1$ & $10 / \%$ & r/AFD & $1 F / 94$ & $1 / 091$ & IV/A. & r/FHF & $\mid \Delta / \cdot V$ & تفكر عاملى \\
\hline$r / \cdot \wedge q$ & $Q / \Delta F$ & $\Gamma / \cdot 11$ & $9 / 4 q$ & T/VIQ & IY/GY & 1/R & $9 / 4$. & تفكر راهبردى \\
\hline$r / q V I$ & YF/QT & $F / \Delta)$. & YF/FY & Y/DTI & $r \cdot / F r$ & r/94. & $Y F / F V$ & اميد به زندگى \\
\hline$r / \mu F_{1}$ & $9 / 71$ & r/৭99 & 9/9. & $r / 9 \Delta \wedge$ & سr/r & rוr & $9 / \wedge$. & استقلال \\
\hline$r / \cdot V \Delta$ & $1 \cdot 191$ & r/9DF & $1 \cdot 1 \cdot v$ & $1 / \Delta \wedge$. & $1 r / 94$ & $r / v V V$ & $1 \cdot / 1 r$ & تسلط بر محيط \\
\hline $1 / A \Lambda \Delta$ & $1 \cdot / A V$ & r/AFq & $1 \cdot 19$ & Y/TAF & $\mid f / f$. & T/VVF & $1 \cdot / \Delta r$ & رشد شخصى \\
\hline l/arb & Q/А. & $r / 99 \mathrm{~V}$ & $9 / 9 \mathrm{~V}$ & Y/VFA & $\mid r / F V$ & r/99Y & $Q / A V$ & دارتباط مثبت بان \\
\hline$r / 90 \Lambda$ & $Q / \Delta F$ & l/GMT & $9 / 4$. & $r / . q r$ & Ir/Tr &.$/ 9 \wedge 9$ & $9 / 9$. & هدفمندى در \\
\hline T/MFF & $9 / V r$ & $1 / 091$ & $q / r$. & $r / A 1 \Delta$ & $11 / 94$ & 1/GYF & $Q / Y V$ & يذيرش خود \\
\hline$V / Y I A$ & $\Delta Q / 9 V$ & Q/vor & $\Delta \Lambda / \Delta r$ & $r / \Lambda \cdot \Lambda$ & $9 \Lambda / 4$. & N/QGY & $\Delta q / Y$. & روانشناختى بستى \\
\hline
\end{tabular}

جدول ₹: نتايج حاصل از تحليل واريانس جُند متغيره بر روى تاب آورى، بهزيستى روانشناختى و اميد به زندگى در بيماران آسماتيك

\begin{tabular}{|c|c|c|c|c|c|c|}
\hline 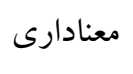 & $\mathrm{F}$ & ميانگين مربعات & درجه آزادى & مجموع مربعات & متغيرها & منبع \\
\hline$\cdot / \cdots$ & Q/QFY & IYN/QV. & 1 & IYN/QV. & تاب آورى & \\
\hline$\cdot / \cdots$ & $I V / I V$ & $F V / Q M M$ & 1 & $F V / Q M A$ & تفكر عاملى & \\
\hline$\cdot / \cdot 1$ & $1 Y / 9 \cdot V$ & $V \Psi / \cdot I V$ & 1 & $V \Psi / \cdot I V$ & تفكر راهبردى & \\
\hline$\cdot / \cdots$ & Fr/rVq & rra/rar & 1 & rrq/rqu & اميد به زندگى & \\
\hline$\cdot / \cdot 1 r$ & $V / \Delta \cdot F$ & AV/rar & 1 & AV/ror & استقلال & \\
\hline.$/ \cdot r$ & $1 \cdot / r \Delta \Delta$ & $94 / \mathrm{MHO}$ & 1 & $99 / \mathrm{MHD}$ & تسلط بر محيط & $\check{\zeta}_{11}$ \\
\hline$\cdot / \cdots$ & IN/IYY & $9 F / 01 T$ & 1 & $9 F / 01 T$ & رشد شخصى & \\
\hline$\cdot / \cdots$ & $M N / F V$ & I.r/vir & 1 & 1.r/vir & ارتباط مثبت با ديخران & \\
\hline$\cdot / \cdots \Delta$ & $9 / 994$ & $\Delta \wedge / q 1$. & 1 & $\Delta \Lambda / 91$. & هدفمندى در زند گى & \\
\hline.$/ . \mu r$ & $F / 9 Y \Lambda$ & $r q / 10 q$ & 1 & $r q / 109$ & يذيرش خود & \\
\hline$\cdot / \cdots$ & $V r / v \wedge$. & YDIN/Y.A & 1 & YDIN/Y.A & بهزيستى روانشناختى & \\
\hline
\end{tabular}


بذيرش و تعهد به علت سازو كارى نهفته در آن مانند يذيرش، افزايش آكاهى، حساسيتزدايى، حضور در لحظه، مشاهدهرى بدون قضاوت، رويارويى و رهاسازى در تلفيق با فنون رفتاردرمانى شناختى سنتى مىتواند ضمن كاهش علائم روانى، اثربخشى را افزايش داده و موجب افزايش تاب آورى، بهزيستى روانشناختى و حتى اميد به زندگى مى گردد( (Y). درمانكران به جاى تمر كز بر تغيير شكل محتوى، به مراجع در يذيرش و داشتن تمايل به تجربه نمودن افكار و احساسات كمكك نموده و با استفاده از فنون ذهن آكاهى بر اصلاح توجه و آكًاهى مراجعين تأكيد مىورزند (rY). اين رويكرد، يكك درمان شناختى رفتارى است كه از مهارتهاى ذهن آكاهى، بذيرش و گسلش شناختى براى افزايش انعطافيذيرى روانشناختى استفاده مى كند (·). در اين درمان هدف از تاكيد بسيار بر تمايل افراد به تجربههاى درونى اين است كه به آنها كمكك شود تا افكار آزاردهندهشان را فقط بهعنوان يكك فكر تجربه كنند و از ماهيت ناكارامد برنامه فعلىشان آكاه شوند و بهجاى بِاسخ به آن، به انجام آنجه در زندگى برايشان مهم و در راستاى ارزشهايشان است، ببردازند (YD) ايجاد ارتباط باتجربهشان در زمان حال و بر اساس آن جه در آن لحظه براى آنها امكانيذير است، ناشى مىشود. در اين درمان تمرينهاى تعهد رفتارى به همراه فنون گسلش و يذيرش و نيز بحث هاى مفصل بيرامون ارزشها و اهداف فرد و لزوم تصريح ارزشها، همكى منجر به افزايش ميزان تاب آورى، بهزيستى روانشناختى و اميد به زندگى و ابعاد آن شامل تفكر عاملى و تفكر راهبردى در بيماران آسماتيك شد. هم جِنين افزايش در خرده مقياس هاى بهزيستى روانشناختى شامل استقلال، تسلط بر
نتايج اين آزمون حاكى از آن است كه در مجموع بين خرده مقياس استقلال (Y)

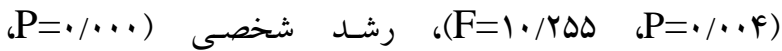
(F=IN/IYY

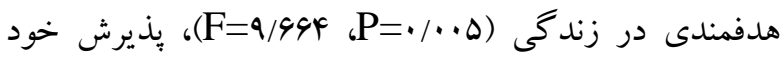

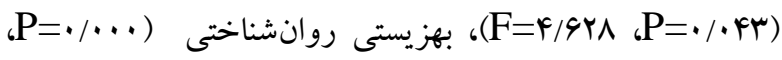
.

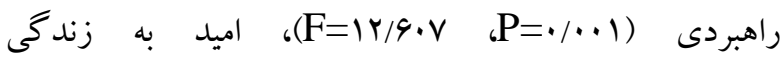

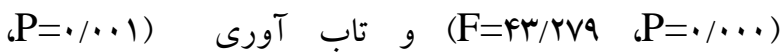
(F=9/Qkr ״ّ آزمون تفاوت معنادارى وجود دارد. كه به طور كلى حكايت از اثر درمان مبتنى بر پذيرش و تعهد بر تاب آورى، بهزيستى روانشناختى و اميد به زندگى در بيماران آسماتيك

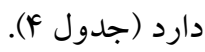

\section{بحث و نتيجه كيرى}

هدف اين ئزوهش بررسى اثربخشى درمان مبتى بر بذيرش و تعهد بر تاب آورى، بهزيستى روانشناختى و اميد به زندگى در بيماران آسماتيكك با سلامت روان پايين بود و با توجه به نتايج تحليل انجام شده، درمان مبتى بر بذيرش و تعهد بر تاب آورى، بهزيستى روانشناختى و اميد به زندگى در بيماران آسماتيكك اثر داشته و موجب افزايش اين متغيرها شده است. در همين راستا يُزوهشها نشان دادند كه درمان مبتنى بر يذيرش و تعهد باعث افزايش تاب آورى (YF)، بهبود وضعيت روانشناختى و افزايش تاب آورى و انعطاف روانشناختى (Y))، ارتقا سلامت و بهزيستى روانشناختى (YD)، و افزايش بهزيستى روانشناختى مؤثر است  
ريه كلينيك ويزه شهر سارى و محدود بودن به بازه ى سنى r. تا .9 ساله و محدوديت به زمان اجراى بزوهش در باييز لهَا. هم حنين با توجه به فرايند درمان افراد توسط مراكز امكان دريافت مراحل بيخيرى طولانى تر ميسر نبود. اين يزووهش نشان داد كه درمان مبتنى بر بذيرش و تعهد بر تاب آورى، بهزيستى روانشناختى و اميد به زندگى در بيماران

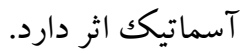

هم جنين اين درمان باعث بهبود ابعاد اميد به زندگى شامل تفكر عاملى و تفكر راهبردى و خرده مقياس هاى استقلال، تسلط بر محيط، رشد شخصى، ارتباط مثبت با ديخران ، هدفمندى در زندكى و يذيرش خود نيز شده است. بنابراين روانشناسان، روانيزشكان و ساير درمانكران در مراكز درمانى مىتوانند از اين درمان براى كاهش شدت علايم و افزايش بهزيستى روانشناختى، تاب آورى و اميد به زندگى بيماران استفاده كنند و با آموزش تكنيك هاى بسيار كارآمد اين روش درمانى مانند كنترل هيجانى و شناختى مى توان سبب بِاسخ هاى موثر اين افراد در شرايط بِرفشار گردد.

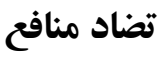
اين يزوهش هيج گونه تعارض منافعى با هيج سازمانى در ابعاد

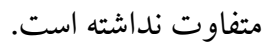

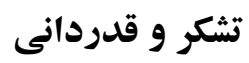
نويسندكان از تمامى بيماران شركت كننده در يزوهش بابت همكارى در اين يُزوهش و هم جنين كلنيك ويزه سارى تشكر

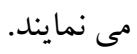

محيط، رشد شخصى، ارتباط مثبت با ديخران ، هدفمندى در زندگى و يذيرش خود نيز واضحا ديده شد. در اينجا با جايگزين كردن خود به عنوان زمينه، بيماران آسماتيك توانستند رويدادهاى درونى ناخوشايند رادر زمان حال به سادگى تجربه كنند و قادر به جدا كردن خود از واكنشها، خاطرات و افكار ناخوشايند شدند. در واقع به آنها آموزش داده شد كه در درمان يذيرش و تعهد جِكونه فرايندهاى مركزى بازدارى فكر را رها كنند، از افكار آزاردهنده رهايى يابند، به جاى خود مفهومسازى شده، خود مشاهده جاى كنترل ببذيرند، ارزشهايشان را تصريح كنند و به آنها بيردازند. هم جنين، در اين درمان افراد ياد مى گيرند كه احساساتشان را بيذيرند تا اينكه از آنها فاصله بخيرند و به افكار و فرايند تفكرشان به وسيلهى ذهن آكاهى بيشتر برداخته و آنها را در جهت فعاليتهاى هدف محور بيوند دهند (·r). درمان مبتنى بر بذيرش و تعهد و فنون آن، مشاهده و توصيف بدون قضاوت تجارب در زمان حال را تشويق مى كند، جيزى كه به عنوان يكك فرايند دانستن از آن ياد مى شود (צ؟). به طور خلاصه، درمان بذيرش و تعهد تلاش مى كند تا به افراد ياد دهد كه افكار و احساساتشان را تجربه كنند؛ به جاى اينكه تلاش كندآنها را متوقف سازند، و از افراد خواسته مىشود كه در جهت اهداف و ارزشهايشان كار كنند و افكار و احساسات خود را تجربه كنند. البته بايستى در نظر داشت كه اين يزوهش با محدوديتهاى تحقيق روبرو بوده است از جمله محدود شدن يُزوهش به بيماران آسماتيك با سلامت روان بإيين در درمانگاه

\section{References}

1-McLeish AC, Kraemer KM, OBryan EM. Discomfort Intolerance in Relation to Asthma Outcomes. Cognitive Therapy and Research.2019; 43(1):24-31. 
2-Johnson AL, OBryan EM, Kraemer KM, McLeish AC, Zvolensky MJ, Bernstein JA, et al. The role of anxiety sensitivity-physical concerns in terms of quit day withdrawal symptoms and cravings: A pilot test among smokers with asthma. Journal of Asthma. 2019; 56(2): 173-8.

3-Alsaid-Habia T, McLeish AC, Kraemer KM. Associations between distress tolerance and asthma symptoms and quality of life. Journal of Asthma. 2019; 56(10):1120-7.

4-Rahmawati P, Muljohardjono H, Wibowo A. Meaning behind illness: Emotional healing among asthma patients. Drug Invention Today. 2018; 10(7): 42-59.

5-Chang SJ, Kwak EY, Hahm BJ, Seo SH, Lee DW, Jang SJ. Effects of a meditation program on nurses' power and quality of life. Nursing science quarterly. 2016;29(3):227-34.

6-Hegney DG, Rees CS, Eley R, et al. The contribution of individual psychological resilience in determining the professional quality of life of Australian nurses. Frontiers in psychology. 2015; 6: 1613-24.

7-Connor KM, Davidson JR. Development of a new resilience scale: The Connor-Davidson resilience scale (CD-RISC). Depression and anxiety.2003;18(2):76-82.

8-Wu WW, Tsai SY, Liang SY, Liu CY, Jou ST, Berry DL. The mediating role of resilience on quality of life and cancer symptom distress in adolescent patients with cancer. Journal of Pediatric Oncology Nursing.2015;32(5): 304-13.

9-Trompetter HR, Bohlmeijer ET, Lamers S, et al. Positive psychological wellbeing is required for online self-help acceptance and commitment therapy for chronic pain to be effective. Frontiers in psychology.2016;7:353-369.

10-Brown M, Glendenning AC, Hoon AE, et al. Effectiveness of web-delivered acceptance and commitment therapy in relation to mental health and well-being: a systematic review and metaanalysis. Journal of Medical Internet Research.2016;18(8):221-34.

11-Khanjani M, Sohrabi F, Aazami Y. The effectiveness of resilience and stress management training program on psychological well-being, meaning of life, optimism, and satisfaction of life in female-headed households. Iran J Psychiat Nurs.2018; 6(2):1-11.[Persian]

12-Mathew J, Dunning C, Coats C,et al. The mediating influence of hope on multidimensional perfectionism and depression. Personality and Individual Differences.2014;70: 66-71. 
13-Arslan C, Oral T, Karababa A. Examination of Secondary School Students' Hope Levels in terms of Anxiety, Depression and Perfectionism. Egitim ve Bilim Education and Science. 2018; 43(194):101-10.[Persian]

14-Tahmasbipour N, Nasri S, Rafieeyazd Z. The relationship between spiritual intelligence, life expectancy, and self-regulation among high school students. Bali Medical Journal. 2018; 7(2): 399406.[Persian]

15-Yalcın I, Malkoc A. The relationship between meaning in life and subjective well-being: Forgiveness and hope as mediators. Journal of Happiness Studies.2015; 16(4): 915-29.

16-Mishra PR, Vashist KA. A review study of spiritual intelligence, stress and well-being of adolescents in 21st century. International Journal of Research in Applied Natural and Social Sciences.2014;2(4):11-24.

17-Meybodi AR, Doosthosseini F. The Effect of Spiritual Health on Academic Burnout with the Mediator Role of Life Expectancy. Bioethics Journal. 2018; 8(28): 39-47.[Persian]

18-Bricker JB, Copeland W, Mull KE, et al. Single-arm trial of the second version of an acceptance \& commitment therapy smartphone application for smoking cessation. Drug and alcohol dependence. 2017 ; 170: 37-42.

19-Losada A, Marquez-Gonzalez M, Romero-Moreno R, et al. Cognitive-behavioral therapy (CBT) versus acceptance and commitment therapy (ACT) for dementia family caregivers with significant depressive symptoms: Results of a randomized clinical trial. Journal of Consulting and Clinical Psychology.2015;83(4):760-72.

20-Pakenham KI. Training in acceptance and commitment therapy fosters self-care in clinical psychology trainees. Clinical Psychologist.2017; 21(3):186-94.

21-Gross M, Moore ZE, Gardner FL, et al. An empirical examination comparing the mindfulnessacceptance-commitment approach and psychological skills training for the mental health and sport performance of female student athletes. International Journal of Sport and Exercise Psychology. 2018; 16(4): 431-51.

22-Hayes SC, Pistorello J, Levin ME. Acceptance and commitment therapy as a unified model of behavior change. The Counseling Psychologist. 2012; 40(7): 976-1002. 
23-Mahmoodfakheh H, Khademi A, Tasbihsazan R. The Effectiveness of Acceptance and Commitment Therapy on Psychological Happiness and Well-Being of Mothers of Cancer Children. Journal of Pediatric Nursing, 2019; 5(4): 71-78. [Persian]

24-Farahani M, Heydari H. The Effectiveness of Acceptance and Commitment Therapy on Resiliency in People with MS The Rise of Psychology. 2018; 7 (6): 149-62.

25-Passmore HA. Acceptance and Commitment Training (ACT) as a Positive Psychological Intervention: A Systematic Review and Initial Meta-analysis Regarding ACT's Role in Well-Being Promotion Among University Students. Journal of Happiness Studies. 2019; 1: 1-6.

26-Hughes LS, Clark J, Colclough JA, et al. Acceptance and Commitment Therapy (ACT) for chronic pain. The Clinical journal of pain. 2017; 33(6): 552-68.

27-Caulfield JI, Caruso MJ, Bourne RA, et al. Asthma Induction during Development and Adult Lung Function, Behavior, and Brain Gene Expression. Frontiers in behavioral neuroscience.2018;12:188-92.

28-Farrell AK, Slatcher RB, Tobin ET, et al. Socioeconomic status, family negative emotional climate,and anti-inflammatory gene expression among youth with asthma. Psychoneuroendocrinology. 2018; 91: 62-7.

29-Schwartzer JJ, Careaga M, Coburn MA, et al. Behavioral impact of maternal allergic-asthma in two genetically distinct mouse strains. Brain, behavior, and immunity. 2017; 63: 99-107.

30-Hayes SC, Wilson KG, Gifford EV, et al. A preliminary trial of twelve-step facilitation and acceptance and commitment therapy with polysubstance-abusing methadone-maintained opiate addicts. Behavior therapy. 2004; 35(4): 667-88.

31-Jokar B. The mediating role of resilience in the relationship between emotional intelligence and general intelligence with life satisfaction. Contemporary Psychology Quarterly, 2007; 2(2): 312.[Persian]

32-Snyder CR, Harris C, Anderson JR, et al. The will and the ways: development and validation of an individual-differences measure of hope. Journal of personality and social psychology. 1991; 60(4): 570-81.

33-Aladdin Z, Kajbaf MB, Molavi H. The Effectiveness of Hope Group Therapy on Hope and Mental Health. Journal of Research in Psychological Health. 2008; 1(4): 48-56. [Persian] 
$4 \Lambda$

34-Ryff CD, Singer BH, Seltzer MM. 12 Pathways through challenge: implications for well-being and health. Paths to successful development: Personality in the life course. 2002; 4: 302-21.

35-Goldberg D. The detection of psychiatric illness by questionnaire. London: Oxford university press.1972;(4):34-42.

36-Noorbala A, Bagheri Yazdi SA, Mohammad K, et al. Mental health survey of the adult population in Iran. The British Journal of Psychiatry.2004; 184 (1): 70-81.[Persian] 